\title{
Panic over bird flu pandemic premature, experts say
}

Fears of a bird flu pandemic heightened in January when scientists reported that samples of $\mathrm{H} 5 \mathrm{~N} 1$ taken from infected individuals in Turkey carry mutations that could enable the virus to spread more easily among people. But experts now say the news may have raised red ๖ flags prematurely.

"Some of the initial enthusiasm for the results may have been overinterpreted," says Alan Hay, director of the World Health Organization (WHO) collaborating laboratory in London that is analyzing samples from Turkey and Iraq. "It's not apparent that these [genetic] differences have a dramatic impact on pandemic potential."

Hay and others say that because mutations are a defining feature of the influenza virus, it is not surprising that researchers found tiny genetic differences between the Turkish H5N1 samples and other strains of the virus.

Carrying RNA instead of DNA, influenza viruses mutate constantly because the enzyme that generates RNA makes frequent mistakes during replication. But scientists say it's unlikely that just one or two genetic reshuffles could give rise to a complex and potentially lethal virus that is fully adapted to humans.

"These viruses have ten different genes and eight different pieces of RNA which all have to work together and evolve together and mutate

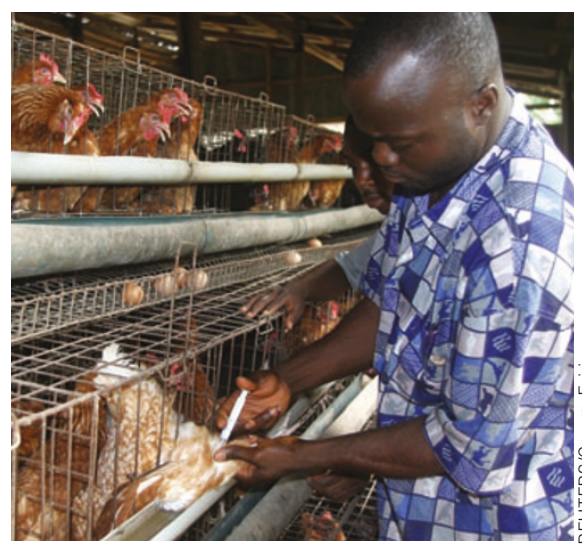

Fowl fears: There's no sign that the H5N1 virus, which has spread to Africa and Europe, has become more dangerous to people.

together and adapt together," says Michael Perdue, a senior scientist with the WHO's Global Influenza Program. "One change doesn't automatically mean a new virus."

Still, one of the three Turkish mutations, noted before in Hong Kong and Vietnam, worried researchers. The change is an amino acid substitution in hemagglutinin - the ' $\mathrm{H}$ ' of H5N1-a key surface protein that enables the highly pathogenic virus to invade foreign cells.

"This is an important observation and a worrying one that the virus is more able to associate with human receptors and human cells," says Robert Webster, a virologist at St. Jude Children's Research Hospital in Tennessee. Due to the virus' inherent propensity to change, however, Webster adds that public health authorities must adopt a wait-and-see approach, acting only when human-to-human transmissions start to appear.

That hasn't happened yet. Nearly all 161 human cases of avian flu thus far have resulted from direct exposure to wild or domestic infected birds.

Meanwhile, researchers are trying to pinpoint why some $\mathrm{H} 5 \mathrm{~N} 1$ mutations are more virulent then others. Taking a big step in that direction, bioinformaticist Clayton Naeve in January released sequence information for 169 strains of avian influenza and 2,196 additional avian flu genes, effectively doubling the available information on avian flu strains (Science doi:10.1126/science.1121586).

"All of these traits we speak about, like transmissibility and virulence, are multigenic traits," says Naeve, who used duck, poultry and other avian viral strains stored in a vast viral repository maintained by Webster. "With a more detailed analysis of this huge new amount of genetic data, we will have a better ability to understand multigenic traits for the first time."

Paroma Basu, Madison

\section{One year after launch, drug safety board is dubbed a failure}

A new drug safety board at the US Food and Drug Administration (FDA) is failing in its declared goal of increasing openness and transparency at the agency, members of an FDA advisory committee said in February.

Exactly a year ago, the FDA announced with much fanfare the launch of a new panel aimed at improving the agency's management of drug safety issues_-including releasing early warnings when safety issues begin to emerge. The agency's announcement came five months after Merck withdrew Vioxx when a study showed that the painkiller doubles the risk of strokes and heart attacks after 18 months of use.

The agency's plan was in part a response to growing public sentiment that that it had been lax about drug safety. Speaking at the time, US Department of Health and Human Services Secretary Mike Leavitt hailed the "independent" panel as the harbinger of a new "culture of openness" at the FDA.

But on 10 February, an advisory committee gave a very different verdict after hearing an update on the board's progress.

"You are setting yourself up for failure with this oversight board," said Peter Gross, the committee chairman and chair of internal medicine the Hackensack University Medical Center in New Jersey. "[The board] meets in private; it has no public representatives. All the people on the board are beholden to the government," he noted. "This process of oversight has to be more transparent."

The drug safety board has 15 voting members, 13 of whom are senior scientific managers at the FDA; the other 2 are staff physicians at the National Institutes of Health and the Department of Veterans Affairs. Members meet in closed sessions every month or two. As of mid-February, they had issued safety alerts on 44 drugs, including 3 that have been suspended and 2 that have been withdrawn. But the board has not yet established a website, dubbed 'Drug Watch,' that was promised a year ago to help the public access these alerts.

Arthur Levin, a committee member who directs the New York-based Center for Medical Consumers, says an 'oversight' board should have the independence and power to objectively assess drug safety errors made by the agency. He pointed to the National Transportation Safety Board, which is called in to determine the cause of airplane crashes, as a model. Without that independence, he said, the board's name-Drug Safety Oversight Board- "is extremely misleading to the public.”

Senior FDA managers were quick to defend the board's closed meetings. Because the board's discussions include information proprietary to drug companies, they said, board members are bound by law to keep them private. "It's not because the FDA wants to withhold information," said Sandra Kweder, deputy director of the agency's Office of New Drugs. Instead of thinking of the board as an external monitor of drug safety, she added, it should be seen as "a supplement" to the regular work of agency staff.

Meredith Wadman, Washington, DC 